\title{
SECOND HOME TOURISM IN LIGHT OF THE HISTORICAL-POLITICAL AND SOCIO-GEOGRAPHICAL DEVELOPMENT OF CZECHIA AND SWEDEN
}

\begin{abstract}
VÁGNER, J., MÜLLER, D.K., FIALOVÁ, D. (2011): Second home tourism in light of the historical-political and socio-geographical development of Czechia and Sweden. Geografie, 116, No. 2, pp. 191-210. - The article presents a comparative study of the evolution, present state, location, regulation, trends and perspectives of second home tourism and its research in Czechia and Sweden as examples, respectively, of a CentralEuropean, post-communist and a Nordic country. The results are based on long-term research on second housing at Charles University in Prague and Umeå University in Sweden. A broad range of literature, along with extensive personal experience, proves that second housing processes and factors influencing the ownership and location have much in common, regardless of differing historical, socio-economic and political backgrounds. Such processes are related to specific lifestyle and leisure practices in combination with activities in nature as well as stages in the urbanization process. Social and subjective factors prevailed the political (and economic) terms. The Nordic countries exhibit comparable absolute and relative data on second homes, similar schemes of recreational commuting and trends concerning the transformation of second homes into permanent dwellings, or the dissolution of differences between the utilization of both types of homes. Other common features can be found in commercialization and internationalization in recent decades. Changes in second housing should be explored in light of demographic changes in terms of owners and users, tax policies and the development of recreational municipalities. Generally, the trends reflect the changes in mobility with the shift of tourism society toward leisure society.
\end{abstract}

KEY WORDS: second home - tourism - Czechia - Sweden.

The research was supported by the Grant Agency of the Czech Republic, Project No. $43 / 03 / 1491$ "The significance of recreational function of settlements and municipalities in the process of forming regional identity and identity of regions in the Czech Republic".

\section{Introduction}

European societies are increasingly characterized by greater access to leisure, tourism and mobility. This is also manifested in long-term interest in the possession and use of second homes (Hall, Müller 2004; Gallent, Shucksmith, Tewdwr-Jones, eds. 2003). Widespread ideas about spending time in one's own leisure home reflect the transition from industrial society towards post-industrial and globalized society (Kaltenborn 1998). However, in addition to this transformation, the ageing of societies as well as improvements in infrastructure create preconditions for a greater amount of households to be interested in second home ownership (Müller 1999).

This interest in second homes has also been acknowledged in research (Coppock 1977; Hall, Müller 2004). Accordingly, second homes can be found, 
primarily, in countries with major tourist amenities and in countries with extensive territory, low population density and, often, late urbanization (Kowalczyk 1994). For the latter, second homes provide a link not only to the countryside, but also to a rural heritage. In a European context, this can be found mainly in the Nordic countries, where second home use dates back to the 19th century (Müller 2007). Against this backdrop, it may be surprising to note that Czechia, in contrast with many other countries in Central Europe, also has a considerable amount of second homes and a long tradition of second home use (Vágner, Fialová et al. 2004; Vágner 2003). Thus, there should be other reasons, beyond simply access to suitable land, that explain the second home phenomenon. For example, traditions, household economy and government regulations can be expected to influence the development over time. This makes the comparison of Sweden and Czechia particularly interesting. Post-war preconditions for private property ownership obviously differed between the countries. This should then also affect the way scientific findings can be transferred between national contexts. A lack of comparative studies highlighting the role of national institutions in second home tourism gives rise to the idea of exploring whether models of second home development can be transferred from the Nordic countries to Czech conditions and vice versa.

The point of departure for this article is the assumption that the origins and also current trends and perspectives regarding second home tourism may be, in many aspects, analogous in both Czechia and the Nordic countries. The similarities and differences in the development, structure of the owners, the recent trends (internationalization, commercialization) are surveyed in Czechia and Sweden. The purpose of the article is to analyze the impact of different policy regimes on the development of second homes in Czechia and Sweden as examples, respectively of a Central European, post-communist country and a Nordic country. Primary questions are: What essential factors have influenced the development of the second housing structure? Is it possible to find similarities in the Czech and Swedish models of development, structure and spatial distribution of second homes? What leading driving forces can be revealed? What are the latest trends? Were the different political systems the essential factors for the second home tourism development and the distribution of the second homes or have other factors (economic, social, subjective) prevailed?

The contribution represents a result of an international cooperation in second home, leisure, recreation and tourism research, which includes Charles University in Prague (Czechia) and Umeå University in Sweden and additional connections with other Nordic (Lillehammer College, Norway; University of Joensuu, FUNTS Savonlinna, Finland) and Central-European universities (Comenius University Bratislava in Slovakia; Uniwersytet Warszawski in Poland). We attempt to make a comparative study, based on an explanation of historical developments concerning second homes and results of second home research, spatial distribution and regulative instruments in both countries. Current trends are then defined, highlighting processes and driving forces, which are presumed to influence current and future development. To achieve this, we review previous research and use the recent and current survey results on second homes, conducted at the institutions mentioned above. 
Definitions of second homes are not unanimous and vary significantly (for a broader discussion on second home definitions see Hall, Müller (2004, pp. 4-6), Vágner, Fialová et al. (2004, pp. 26-28). For the purpose of this study, we use Shucksmith's (1983, p. 174) second home definition: "a permanent building which is the occasional residence of a household that usually lives elsewhere and which is primarily used for recreation purposes". It should, however, be mentioned that statistical practices in the countries in question imply certain minor variations in the definitions applied. Moreover, the analysis is restricted to rural second homes.

\section{Factors of second home ownership and location}

Although second homes in different countries may be similar, in terms of physical structure and location, the origin and development was framed by varying preconditions. Here, we suggest that second home development is influenced by the interrelated political, social, economic, demographic and subjective factors (Table 1). The factors are effective at all hierarchical levels (global to local, complex systems to individuals).

Political and ideological systems favor specific forms of leisure activities. Second homes were a typical segment of tolerance for communist regimes,

Table 1 - Factors influencing the ownership and location of second homes

\begin{tabular}{|l|l|}
\hline \multicolumn{2}{|l|}{ Ownership factors } \\
\hline Political, institutional, legislative & $\begin{array}{l}\text { political system, housing, tax policy, } \\
\text { internationalization }\end{array}$ \\
\hline Social, psychological and cultural & $\begin{array}{l}\text { urbanization - leisure needs and demands, life- } \\
\text { style, social status, income, "self-realization" }\end{array}$ \\
\hline Economic & $\begin{array}{l}\text { stage of economic development, quality and type of } \\
\text { residence }\end{array}$ \\
\hline Demographic & age, gender, education, profession \\
\hline Subjective (individual) & $\begin{array}{l}\text { heritage, origin, family relationships, former } \\
\text { residence }\end{array}$ \\
\hline Location factors & $\begin{array}{l}\text { rural depopulation, agglomeration effects, } \\
\text { population density, suburbanization, } \\
\text { deurbanization }\end{array}$ \\
\hline Stage of urbanization processes & $\begin{array}{l}\text { natural recreation potential for recreation, } \\
\text { landscape degradation }\end{array}$ \\
\hline $\begin{array}{l}\text { Landscape and environmental } \\
\text { quality }\end{array}$ & $\begin{array}{l}\text { transport, road quality } \\
\text { technical infrastructure (water supply, sewage), } \\
\text { shops }\end{array}$ \\
\hline $\begin{array}{l}\text { Accessibility (transport, road } \\
\text { quality) } \\
\text { Infrastructure and service quality }\end{array}$ & $\begin{array}{l}\text { housing, financial (tax) policy, regional policy, } \\
\text { master planning }\end{array}$ \\
\hline Institutional factors & see above (ownership factors) \\
\hline Subjective factors &
\end{tabular}

Source: own elaboration, inspired by Kowalczyk 1994 
also due to lack of commercial tourism offer. Legal settings influence the availability of and access to second homes. Major components in this area include laws and regulations influencing property ownership, housing and tax policy, institutional influence on the length of disposable leisure time (free Saturdays, increasing number of holiday days) and other similar factors and significantly determine location of second homes. For example, bans on foreign property ownership influence the second home market (Müller 1999). Within tourism research, the role of regulation has been highlighted (Williams 2004).

Different regimes of land ownership and accessibility influence the amount of available land for new second home development (Gallent, Shucksmith, Tewdwr-Jones, eds. 2003). On the contrary, cottages as houses built primarily for non-recreational function offer a big potential with no other land requirements, with additional profit from rescue of abandoned houses. A situation with many small rural landholders is expected to create a higher number of second homes. This is due, in part, to the likelihood that small landholders keep their property even when discontinuing agriculture. In contrast, large landholders are less likely to sell land for second home development since access to land is, in fact, a precondition for continuing agriculture or forestry.

The development of the social and economic systems also influences the availability of and access to second homes. The transition from an agricultural, to an industrial, to a post industrial or service-based economy initially created the preconditions for second home living (higher share of leisure time, increase of disposable capital), and subsequently extended its accessibility to broader groups of society. Moreover, the corresponding restructuring of rural areas caused a surplus of rural housing that could be used as second homes (Müller 2004).

It has been argued that even globalization causes increased interest in second homes as they represent a stable component of life, featuring comprehensive experiences in an otherwise quickly changing and alienated, everyday world (Kaltenborn 1998). Commercialization and internationalization of second home market are typical examples of current trends.

Social and economic factors are based on the urbanization of the life-style (higher aspirations for leisure activities and second home ownership) and on the social status, need for "self-realization" in second home activities. The level of income is close to the economic factors which include also quality of the residential dwelling.

Urbanization and the presence of a middle class favor second home development through the depopulation of rural housing fund and offer for functional changes, partly because of a tendency to romanticize rural living and the subsequent desire to maintain a connection with a rural area (Bunce 1994), and partly due to their access to economic means that can be utilized for leisure and tourism. This must be viewed as something different than allotment gardens and dachas, facilitating access to gardening space for urban proletarians.

Societal movements acknowledging the importance of nature and outdoor recreation for maintaining health and a sense of wellbeing impact the development of second homes positively. In this context, second homes are seen as a node for excursions and recreation. This can, for example, be seen in the North American situation, where second homes are reminiscent of frontier life and represent an authentic lifestyle (Wolfe 1977). 
The demographic factors include the age, gender, education and professional status of the owners and users of the second homes. Tombaugh (1970) declared the majority of the second home owners are with higher social status, intellectuals, entrepreneurs, well-off retirees. To the contrary, Czechia indicates higher share of the middle- and lower-class owners issued from some specific historical and social roots (tramping, gardening) and the equalization under communism. The second home ownership reflects the life-cycles. The pre-retirement and young retiree groups are the major owners. Young families are in increase related also to the functional shift towards the seasonal and permanent dwellings.

Subjective, individual psychological factors are determined by family relationships, the origin and childhood of the owners. Those factors seem to play an essential role but are not available from traditional data sets and require detailed questionnaire surveys.

The spatial distribution of second homes is, even more than the factors of the ownership and demand, dependent on the level of urbanization processes, rural depopulation, environmental quality and landscape patterns, accessibility, infrastructure and service quality. Regional policy and master planning represent significant institutional instruments.

Factors explained above influenced upon the evolution of second homes, evidences of which are given in the following chapter.

\section{Evolution of second homes}

\subsection{Initial development}

Several phases of development, during the 20th century, which led to the current number and regional distribution of second homes, may be distinguished (Fig. 1). The Nordic countries, as well as certain Central-European states, with Sweden and Czechoslovakia serving, respectively, as prominent examples, have experienced the tradition of summer houses, which contributed to a germinal stage of seasonal suburbanization. Around 1900 in most developed European countries, the U.S.A, Canada, Australia and New Zealand, the recreational potential of the countryside was acknowledged, particularly by wealthy urbanites, artists and intellectuals, with the perception of a rustic idyll as a source of inspiration for their ideas (Coppock 1977; Hall, Müller 2004). In some instances, this movement also led to the penetration of an urban style of architecture and lifestyle into rural areas, with the development of new summer villas.

Researchers noticed the importance of secondary residences as significant elements in the landscape and settlement patterns, as early as the 1930s (Miege 1934). The Stockholm archipelago in Sweden was one of the first regions where summer houses of urban people were surveyed (Ljungdahl 1938). Already by the late 19th century, affluent merchants from nearby Stockholm built rather opulent summer houses to flee the uncomfortable city. Second homes were located along the steamboat lines, facilitating convenient access. Initial studies on recreational settlements in the contemporary Czech area were also conducted (Poser 1939, Joura 1944). 


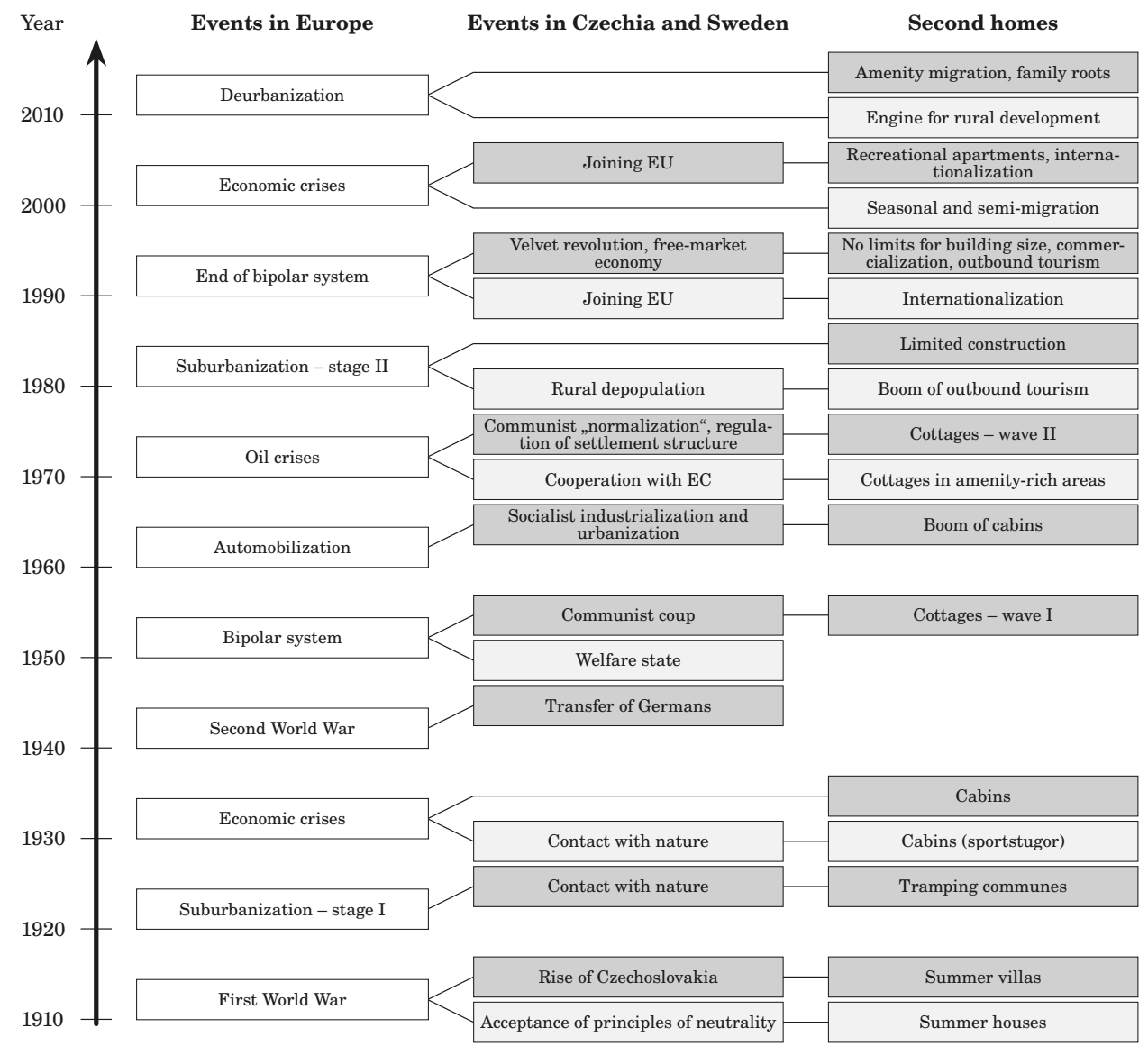

Fig. 1 - Development of second homes in Czechia and Sweden. Source: own elaboration.

Similar natural preconditions and sufficient environmentally rich areas could be found in close proximity to the larger cities, which enabled escape from busy agglomerations even to the lower class and young people. In the early 1920s, a unique tramping movement developed in Czechoslovakia. It was a characteristic expression of the longing for nature inspired by Western movies, books, woodcraft and World War I legionnaires, all of which were imbued with a common theme of nature and decreased environmental burden or damage. Urban outskirts close to busy agglomerations and possessing outstanding natural preconditions were settled temporarily in newly constructed simple log-cabin ("chata") communes. Cheap public railway along the river valleys facilitated weekend commuting. 23,000 second homes existed in Czechia in 1930 (Gardavský 1977). Second homes comply with a strong public association connected to nature and rural life.

Similarly, Sweden experienced a cabin-movement (sportstugor), during the first decades of the 20th century, allowing even members of the middle class to 
experience vacations in the countryside (Nordin 1993). This development led to the duplication of merchants' summer houses by members of the growing urban middle-class. The basic idea was that the cabins could be moved to other places when the owner so desired. However, only a few households ever used this opportunity and, thus, these cabins formed the origin of second home living in Sweden. Moreover, their locations produced a spatial pattern, highlighting highly accessible areas on the outskirts of the then small cities, that remains relevant in the 21st century. In comparison with the Czech tramping tradition, this movement should also be seen in the context of a general interest in contact with nature as a means of maintaining health and sanity.

\subsection{Expansion of second home living}

World War II marked a fundamental historical milestone for all of Europe and the resulting political changes led to the establishment of a bipolar system with different economic and social development. However, even in the post-war decades, certain processes which operated in different ways, but brought similar results, may be observed on both sides of the Iron Curtain.

In Czechoslovakia, nearly 3 million Czech Germans were removed from a large part of the borderlands in 1945 and 1946, mostly as a reprisal for their direct or silent support of the Nazi regime. The communist coup of 1948 substantially influenced the further development of the country, over the next forty years. Massive heavy industrialization resulted in the accelerated movement of people from the countryside to towns. Consequently the residential function of rural areas declined and many vacant houses were left in depopulated areas. These events and processes supported the development of second houses in cottages ("chalupa"), houses which were not originally intended or built for recreation. State propaganda preached support for the reproduction of the physical and mental forces of the people as well as overall personality development. The penetration of urban lifestyle into rural areas was evident and necessitated the more or less spontaneous regulation of new relationships between newcomers and the rural population. Within urban agglomerations and along their edges, garden allotment houses continued the pre-war tradition of self-sufficiency and social activities.

Sweden suffered only indirectly from the war and, because industries were only affected marginally, the Swedish economy boomed. This led to considerable urbanization. Thus, it was primarily the welfare state system which considered tourism and leisure a social issue and, consequently, which supported outdoor activities within the country as a meaningful way of spending free time and holidays. Car ownership soon became widespread in Swedish society, making second homes accessible to broad groups of society. Until the 1980s, government programs sought to expand the supply of second homes, facilitating leisure activities for almost all classes of society (Müller 1999). For that purpose specifically planned areas in attractive locations were designated to satisfy growing demand and to secure a high standard of quality. In addition, rural restructuring caused a surplus of unoccupied housing in the countryside that could be used for second home living (Müller 2004). As a consequence, between 1950 and 1980, the number of second homes increased from 200,000 to 
600,000 (Nordin 1993). Hence, in contrast to the Czech situation, the supply of second homes consisted of converted rural housing and purposely built second homes, which were located in amenity-rich areas such as seaside locations, mountain resorts and lakeshores (Aldskogius 1969). However, the latter far outnumber converted rural housing. Second homes were also promoted as a form of investment, particularly in alpine skiing resorts.

Beginning in the late 1960 s, the situation changed dramatically. Political turmoil in Czechoslovakia and the oil crisis are two major events that influenced the development of second home tourism.

After a short period of enlightenment in Czechoslovakia, during the late 1960 s, further hoped-for development was nullified with the invasion of Soviet and Warsaw Treaty troops. Borders to the West were closed and watched carefully. Limited possibilities for travelling, the lack of and poor quality of tourist accommodations and the absolute prohibition of private businesses caused the disillusioned Czech population to "hide" from everyday totalitarian propaganda by seeking some limited privacy at their second homes during weekends and holidays.

Work-free Saturdays, beginning in the early 1970s, contributed to longer weekend trips. Due to the recent nature of urbanization, there were strong family ties with rural houses, based on heritage. Carter (1991, p. 163), however, argues that "... most second homes are not acquired through direct inheritance". Oil crises could not influence the closed communist economy as much as free-market economies and price stability, which was fully controlled by the state, made another boom of new second homes possible, in the 1970s and 1980s (about 10,000 new second homes per year). This boom created new summer and weekend settlements. The high environmental burden along with the generally strange and poor architectural, aesthetic and construction quality, is characteristic of some of the more extreme concentrations of new recreational houses. The regime was quite tolerant and even regulated organized tourism with collective activities sponsored by trade unions and large state enterprises. Children's camps were highly promoted and silent support for second homes was evident. Second home tourism served as a substitution for the strictly limited travelling and free-movement abroad. Cheap and efficient public transport compensated for the shortage of private cars. Also, regulations governing the construction of new recreational houses and cabins were very benevolent and not strictly enforced. A small tax fee was claimed on buildings larger than $25 \mathrm{~m}^{2}$ ( $16 \mathrm{~m}^{2}$ after 1977). Garden allotment houses were not considered second homes and their users paid only a symbolic member fee to the Czechoslovak Gardeners Association. Land below and around the house was officially owned by the state. Agricultural land, however, was strictly protected from conversion to tourist and leisure functions.

Research on individual short-time recreation also appeared, especially in terms of its geographical distribution and location in the close hinterlands of large agglomerations and the capital (Gardavský 1968). The lack of land-use planning later became the focus of such research (Gardavský 1977). The 1970s also saw an increase in second home tourism, with research conducted in Moravia, in the Jeseníky Mts. (Šprincová 1969) and around Brno (Vystoupil 1981). Hall (1991, p. 86) argues "...the growth of second home ownership presented ethical problems reflecting disparities of wealth and connections. The second 
home often acted as a safety valve for a family confined to a small rented urban apartment during the week. In this way the state was relieved of some of the pressure for greater investment in tourism and recreational facilities". The share of commercial tourism was only $21 \%$ in 1987 . Short breaks were strongly family-oriented (Williams, Baláž 2000).

In Sweden, as in the western realm, second home ownership seemed to grow without limit, threatening rural traditions and lifestyles (Coppock 1977). However the oil crisis of the 1970s put an end to this development. First, it meant that travelling to second homes became an economic burden, at least, to less well-off households, but even after the crisis, second homes had clearly lost their appeal, despite continuous governmental efforts to facilitate further expansion. Also, increases to the urban population were largely discontinued (Borgegård, Håkansson, Malmberg 1995). Consequently, the number of urban households desiring a second home no longer increased. Moreover, the growing share of immigrant population, a significant part of continued population growth, lacked a second home tradition.

Another reason for this declining interest in new construction is supposedly the emergence of new leisure and tourism opportunities, such as charter trips to the Mediterranean. Interest in second homes stagnated and was substituted by a remarkable increase in outbound travel as one part of the ongoing globalization processes. However, this change did not imply a decline in second home use, but rather stagnation in new construction. Finally, a growing awareness of and concern for environmental issues led to the emergence of legislation managing natural resources, such as shore lines. This meant that building permits were no longer granted as easily and that new structures were generally only allowed more than 100 meters from the shoreline, which excluded many of the most attractive spots for second home locations. Thus the 1980s also marked an end to the political perception of second homes as means of social policy.

\subsection{Recent trends}

In the late 1980s, the collapse of the bipolar system brought more open space for the free market economy to all of Europe. Czechoslovakia, in addition to being split into two parts, has undergone, as other post-communist countries, an ecstatic transformation from a totalitarian regime to a free-market economy; a transformation, which has also been mirrored in second home development. The frequency of second home commuting and stays has stagnated, primarily due to possibilities to travel, operate businesses and do a large variety of previously limited activities.

Renewed research in the north, beginning in the early 1990s (especially in Sweden, Norway, Finland and Denmark), focused on time-space competition between second home owners and locals (Aronsson 1993), growing seasonal mobility with semi-migration aspects and multiple dwelling strategies (Flognfeldt 2004), higher pressure on rural property markets and possible rural displacement (Marjavaara 2008), as well as the struggle for amenity landscapes and commercialization and internationalization (Müller 1999). The most remarkable change is certainly the increase in foreign second home ownership 
(Müller 1999). Bolstered by Sweden's entry into the European Union, the share of foreign owners, primarily from neighboring Norway, Denmark and Germany, tripled from $2 \%$, in the early 1990s, to 6\% today. In Småland, in southern Sweden, the share of foreign second home owners amounts to nearly $40 \%$.

Thus, during the 1990s, second homes were increasingly perceived as a problem. Müller (1999) reveals trends of commodification and polarization in second home tourism, during the 1990s. In peripheral areas, numbers of second homes increased due to further demographic decline. In contrast, both the demand for and the values of second homes on the outskirts of metropolitan areas and in amenity-rich vacation regions increased dramatically. Second home owners were often blamed for causing these increases in property value and its associated outmigration (Marjavaara 2008). Moreover, trends to convert these second homes into permanent homes were largely counteracted by municipalities, owing to fears of higher costs for the provision of services.

At the same time, with the continuing transformation of rural houses to second homes in the periphery, a reverse process of conversions to permanent residences has been underway in the outskirts of Swedish metropolitan areas for at least two decades. Steineke (2007a) cited about 250,000 people who have settled permanently in their cottages. An analogous trend has been perceived in Czechia as well - $15 \%$ of second homes have been converted to residential use, during the past 15 years (Vágner, Fialová et al. 2004). Tax on second homes is the same in Sweden as on primary homes; owners simply decide which property to register as a second home. There is no category for uninhabited houses. Many of these are claimed as second homes and therefore the actual number of used second homes is certainly lower.

Additional common features include traditional lifestyles and generational coexistence. A weekend house makes separation from one household possible for parents (grandparents) and adolescents (Iglebaek 2007, Cílek 2007). Central European countries have embarked on the long-term Nordic trend of single households (40\% in Norway, 66\% in Oslo - Iglebaek 2007) and divorced couples. In Central Europe, a lack of urban apartments is, at least temporarily, relieved by the use of second homes, which are often better furnished - this is not the case in northern Europe. Modern technology (computers, Internet, cellular phones) makes it possible to work from a residential or temporary address, without needing to commute everyday. The designation of a building as primary, secondary, temporary or seasonal tends to be insignificant.

Late-productive age groups and retirees are, at present, the most frequent owners of second homes and stagnation and even decline in second home tourism is expected, in future years, in light of the low interest of young groups in second home maintenance. It is probably time to initiate further discussion on the meaning of the term "second home" itself. Differences between primary, temporary, seasonal, secondary housing and place of work have become less significant. Telemobility, foreseen by Berry (1970), became the major factor in these changes. Relationships between various professions and second home use, in terms of the frequency and actual time of stays, could be an interesting research agenda. On the contrary, an increasing group of wealthy people from rural residences expressing interest in second apartments in busy urban environments has appeared. More active social life has also been offered in dynamically developing recreational resorts in mountains, at lakes or in 
seashore locations. Differences between individual second home tourism and commercial forms have also diminished. Further research should continue to focus on questions concerning the transition of second homes from inherited family wealth towards an exclusive commodity, as suggested by Müller (2007). Second home users show intensive regional identity with strong family ties. Their role in shaping the identity of rural settlements, landscape and regions should be verified (Fialová, Vágner 2009). Commuting distance is the crucial factor for differentiating the characteristics and perspectives of weekend and vacation homes, with more local benefits. The latter may become a precursor to more permanent retirement or lifestyle migration (Hall, Page 2002).

The advanced lifestyle involves keeping fit (both physically and mentally) and outdoor activities. Central European second home users have recently indicated renewed interest in walking, hiking and cross-country skiing, in addition to mushrooming and fishing - traditional activities also in the North. A significant boom in cyclotourism was observed in both regions, as well as a boom in alpine skiing with huge infrastructural investments. Golf courses have become new elements of the countryside. In Czechia, the number of golf courses has risen dramatically from three to more than eighty, in the last two decades.

The above mentioned trends and processes have been identified and discussed in a much broader European context, e.g. Spain, Portugal, Italy, France, Greece, Cyprus and Russia (Hall, Müller 2004; Iglebaek 2007).

Increasing demand from the new upper and higher middle-class for special services and sport activities in amenity-rich traditional tourist and second home destinations has resulted in the proliferation of recreational apartments in mountain (and lakeshore) resorts. The commercialization and increasing internationalization of the second home activities has led to a boom in this new market segment of real estate agencies $-3-15 \%$ second homes in Czechia are offered for rent with regional differences (Vágner, Fialová et al. 2004).

New buildings with recreational (holiday) apartments have appeared in Czech mountain resorts, during the last decade, either in the form of a re-constructed tourist or other establishment, as a replacement of original buildings or as entirely new structures near the built-up area. Kadlecová (2006) focuses on the viewpoints of the apartment owners, residents, municipality authorities, tourists and investors and put evidences of mostly negative impacts of recreational apartments on both natural and social environment.

Brand-new holiday parks (sets of holiday homes with leisure space, often gated) and holiday villages (sets of independent holiday homes in a cottagestyle) have been established by foreign investors. Foreign clients are lured to summer and winter resorts (Fialová et al. 2009). A protocol, similar to that of Denmark, for instance (Damsgaard 2007), was issued for Czechia after its accession into the EU in 2004. A foreign person is not permitted to buy either land or a house in accordance with a regulation that should remain in force until 2012. However, many foreigners have been acquiring second homes in Czechia by purchasing them through a legal entity, a company, or through a Czech mediator.

An uncontrolled struggle for amenity landscapes can lead to the tourist trap effect and break load limits, resulting in substantial impacts on the environment and residents (Pásková, Zelenka 2002). Local authenticity, which 
provided the original reason for the investment, may disappear. Traditional amenity-rich resorts would also face potential losses in attractiveness.

Many of these developments cannot be seen in northern Europe. For example, inbound pressure on the second home market is not prohibited by law. Instead, foreign second home ownership in Sweden has been growing considerably. Today about 6\% of all second homes in Sweden are owned by foreigners. This is particularly true for areas of southern Sweden, where foreign owners from Norway, Denmark and Germany form the most important groups.

In the 2000 s, the public perception of second homes in rural areas is changing. They are increasingly seen as an opportunity to sustain rural communities that are suffering from shrinking populations. Besides second home owners' demand for services and commodities, municipalities hope that second homes will be converted into permanent dwellings. The government also decided on a revision of the shoreline protection legislation, allowing for renewed exploitation of peripheral lakes for recreation. Thus, second home development is increasingly perceived as a tool for regional economic development.

Second home tourism has been suggested as an engine for rural development and seems to demonstrate more and more counter- and de- urbanization processes, with consequences in increasingly more remote areas, than ever before. Second home tourism, which had been perceived both in Sweden and Czechia as a social issue, has begun to be a competitor to traditional rural functions, in rural space. Considering the decline of agriculture, rural tourism has played a significant role in local and regional economies. Second homes account for $11 \%$ of overall GDP from tourism in Sweden (Müller 2007). Jobs for the rural population continue to be primarily in the service sector. Excess in the housing stock and limited economic base (Hall 2005) are major current problems for most of rural Europe.

\section{Location of second homes}

There are about 680,000 second homes in Sweden (Steineke 2007b) which account for $14 \%$ of all dwellings (Iglebaek 2007). The nearly 400,000 second homes in Czechia (Table 2) comprise an even higher portion $(20 \%)$ of all dwellings, based on the latest relevant data from the census (Population and Housing Census 1991). The most recent census (2001) did not include all second homes; it only counted non-inhabited houses designated for recreational purposes, which account for only about one third of all second homes. For this reason, older data from 1991 are used for broader analyses, as a means of including most buildings that were built primarily for leisure. Since that time, stagnation in new construction and a slow decrease in the total number of second homes have been observed (Vágner, Fialová et al. 2004).

Similarly to Czechia, about one in two Swedish households today have access to second homes (Müller 2007). These shares would be even higher for the urban populations of cities with more than 100,000 inhabitants.

Figure 2 shows the location and intensity of second homes in all the Nordic countries, which enables comparisons between Sweden and its neighbouring countries in terms of the spatial distribution of second homes. Metropolitan areas, including Stockholm exhibit the highest number, density and intensity 
Table 2 - Second home indicators in Czechia and Sweden

\begin{tabular}{|lcccc|}
\hline Country & $\begin{array}{c}\text { Number of } \\
\text { second homes }\end{array}$ & $\begin{array}{c}\text { Second homes / } \\
\mathrm{km}^{2}\end{array}$ & $\begin{array}{c}\text { Second homes / } \\
1,000 \text { inhab. }\end{array}$ & $\begin{array}{c}\text { Household with } \\
\text { second homes (\%) }\end{array}$ \\
\hline Czechia & $396,000^{*}$ & 5.0 & 38 & $11^{* *}$ \\
Sweden & 680,000 & 1.5 & 75 & 22 \\
\hline
\end{tabular}

Source: Steineke 2007b (based on data issued by national statistical offices), *Kučera 1992 (Population and Housing Census 1991), ** Population and Housing Census 2001, own calculation

of second homes (per 1,000 people). Moreover, island destinations (Öland) and coastal areas, particularly in the south, rank among high intensity spots in Sweden, as do mountain resorts in the peripheral central-western region along the Norwegian border. Thus, the patterns confirm Müller's ideas (2004) that overall population patterns and the geography of amenities are the two main factors for explaining the geography of second homes.

Extreme concentrations of second homes in Czechia are found in the central Bohemian metropolitan area (25\%). The recreational hinterland of Prague exhibits a semi-concentric character with a dominant south $(80 \%$ of the second homes owned by Praguers). The high density around other major cities (Brno, Plzeň, České Budějovice) is probably even more significant than in the Nordic countries. More peripheral second home regions are located in the foothills and mountain areas, or along water courses and reservoirs (Fig. 3 - the $1991 \mathrm{Popu}-$ lation and Housing Census provides the most recent, relevant data, concerning all types of second homes; general patterns have not changed significantly in the years after 1991). The distribution in Czechia is more heterogeneous than in the Nordic countries. Cottages in the border regions and in the inner periphery play an irreplaceable role in the preservation of abandoned settlements, resulting from the removal of Germans and the depopulation evoked by industrialization and urbanization processes.

The significantly higher density in Czechia, in comparison with Sweden (comparable to the French Alps or Spanish Mediterranean) results in a much greater environmental burden as well as the necessity of regulation (Steineke 2007a).

The location of second homes along bodies of water is a common characteristic - about one quarter in Czechia (Bičík et al. 2001) and around three quarters in Sweden, due in part to the country's natural setting on the seashore. Nordic cabins, even when built and equipped in a simple way, are for the most part located on larger plots of land, making many outdoor activities possible. Original Czech second homes were primarily situated within a very short, day-tripping distance. Scandinavians, however, also possessed leisure dwellings in the northern periphery, which created a distinction between weekend and vacation second homes. Nonetheless, the mean second home commuting distance, about $35 \mathrm{~km}$, is practically analogous in Czechia and Sweden (Vágner, Fialová et al. 2004; Jansson, Müller 2003).

More frequent long-distance commuting has been enabled with the quickly developing network of high-speed motorways and the boom in car ownership, since the 1960s (delayed by twenty years in Czechia). A growing number of urban middle-class households possesses one second home in the close hinter- 


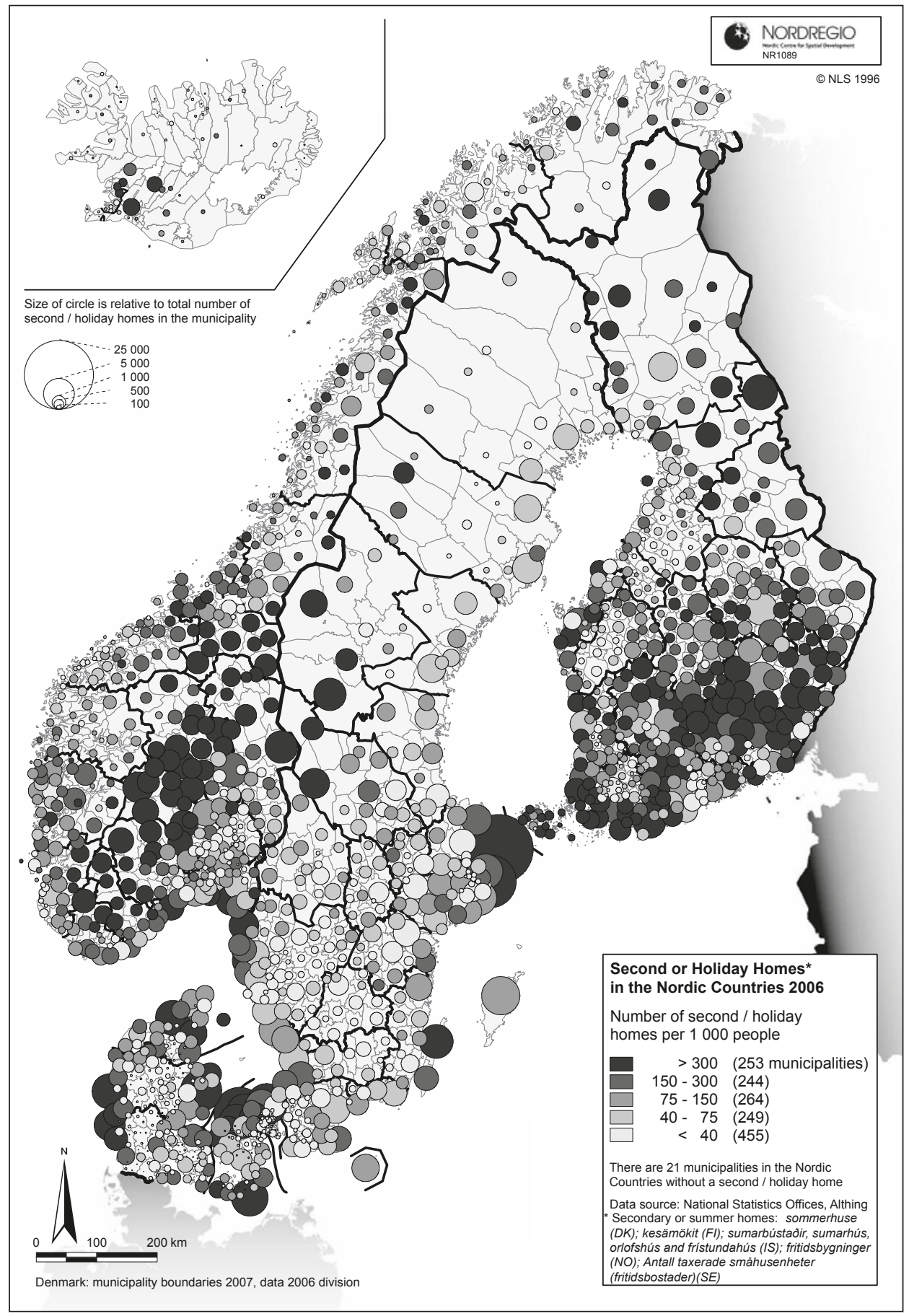

Fig. 2 - Location and number of second homes in the Nordic countries. Source: Steineke 2007b, p. 10 


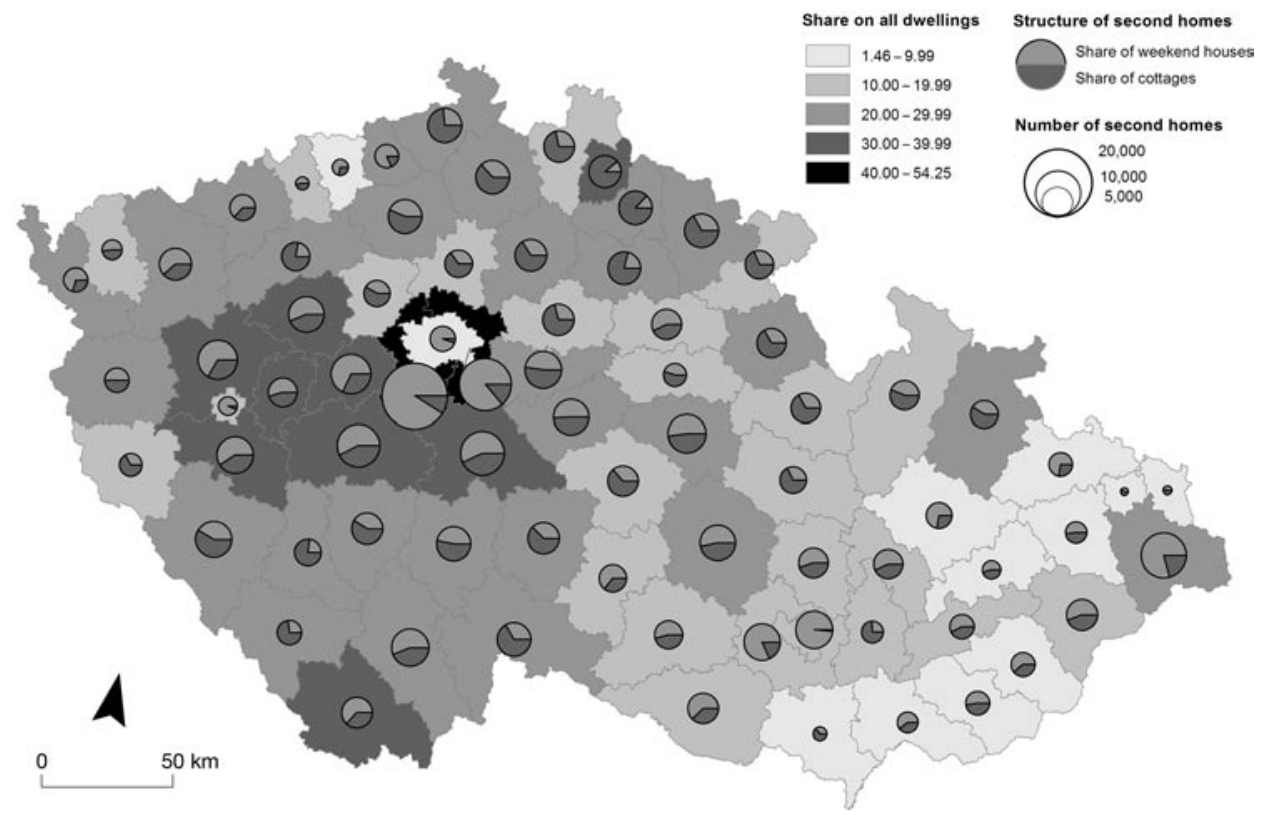

Fig. 3: Location and number of second homes in Czechia. Cabins - light grey colour, cottages - dark grey colour. Source: Vystoupil 2006.

land and another in the remote periphery, with potential for many activities (e.g. alpine skiing). Higher incomes have increased interest in investments into second homes abroad. The seasonal transfer of hundreds of thousands of people from the North to a warm sea, particularly to the Mediterranean, also includes second home tourism. The absence of any sea in their homeland has led some more wealthy Czechs to purchase, lease or time-share a second home on the seashore. Speculation may appear as a decisive factor in second home ownership. On the contrary, some regions of the Nordic countries have been sought after areas for leisure and investments for several decades now. Dozens of thousands of Germans in southern Sweden represent a characteristic example (Müller 1999), with growing demand from Britain, focused more on Norway, and Russia (mostly in Finland). The agricultural countryside has all but vanished in some regions.

The above explained analysis proved that the stages uf urbanization processes and their timing, together with accessibility of second home areas (distance, quality of infrastructure), represent the key factors for distribution of second homes.

\section{Conclusions and perspectives}

Our analysis of the development of second home tourism and its treatment in the scientific literature, as well as a comparison of quantitative and spatial characteristics, reveals a great deal of analogous trends and processes in Czechia and Sweden. The second home tradition can be traced back for nearly 
a century and certain unique log-cabin communes and individual houses are deserving of protective status as architectural pieces of art and symbols of a lifestyle. The essential motives for second home ownership are similar to those pointed out by Bjerke et al. (2006). They may be explained as a removal from or an inversion of everyday life, the experience of informality and relaxed everyday lifestyles, a return to nature, an investment, ideas or ideologies about rurality and, finally, an expression of personal identity. These motives correspond with counter-urbanization or even de-urbanization tendencies. There is a shift from seasonal suburbanization (Pacione 1984) and summer migration towards semi-migration patterns of mobility (Flognfeldt 2004). The inherited ownership and maintenance of second homes demonstrate strong family and generational ties and express the unique personal and regional identity of the owners and users. Leisure homes represent a good means of money allocation and investments. Tax policy is certainly the most efficient instrument for second home development. Low taxes on the secondary housing stock in Czechia are supposed to increase, especially when foreign persons will be allowed to buy houses and land. Such a tax should take into account not only the size of the property, but also environmental load.

A boom in holiday parks or holiday villages provides evidence of the increasingly international character of new second home tourism activities. Central European countries have, so far, been primarily considered as an importing region, while the Nordic countries are viewed as an exporting region. The equalization of prices and economies in Europe brings new trends (Czech interest in fishing cabins on the northern lakes, Czechs renting recreational apartments on the Mediterranean, etc.). Future research should explore effects of the resurrection of domestic tourism during the economic crisis.

Hence, urbanization and rural de-population seem to be the major driving forces, although the availability of suitable land is clearly a precondition for development, because other countries have fewer second homes.

Progress in mobility and technology, along with negative demographic development, contribute to perspectives which, in the shared European space, will result in more or less analogous consequences in Sweden and Czechia. In general, globalization processes have caused many people to turn their thoughts towards less complicated, more understandable and personified local environments. Due to increasing mobility, the "sense of home" has been losing its unique, singular location. Homes are disintegrated and transferred into multiple places. This shift should be reflected with attempts to more deeply comprehend socio-cultural changes in the framework of the expansion of urban lifestyle and new leisure patterns, during the period of the shift from tourist society to leisure society.

\section{References:}

ALDSKOGIUS, H. (1969): Modelling the Evolution of Setlement Patterns. Geografiska Regionstudier, No. 6, pp. 13-26.

ARONSSON, L. (1993): Mötet: en studie i Smögen av turisters, fritidsboendes och bofastas användning av tid och rum. Forskningsrapport Samhällsvetenskap, 93, No. 1, pp. 33-42.

BIĆ́K, I. et al. (2001): Druhé bydlení v Česku. UK v Praze, PřF, KSGRR, Praha, 167 p. 
BERRY, B.J.L. (1970): The geography of the United States in the year 2000. Transactions of the Institute of British Geographers, 51, pp. 21-53.

BJERKE et al. (2006): Cabin Life: Restorative and Affective Aspects. In: McIntyre et al. (eds.) (2006): Multipple Dwelling and Tourism. Negotiating Place, Home and Identity, pp. 79-90.

BORGEGÅRD, L.-E., HÅKANSSON, J., MALMBERG, G. (1995): Population Redistribution in Sweden: Long Term Trends and Contemporary Tendencies. Geografiska Annaler. Series B, Human Geography, 77, pp. 31-45.

BUNCE, M. (1994): The Countryside Ideal: Anglo-American Images of Landscape. Routledge, London, $232 \mathrm{pp}$.

CARTER, F. (1991): Czechoslovakia. In: Hall, D. R. (1991): Tourism and Economic Development in Eastern Europe and the Soviet Union. Belhaven Press, London, pp. 162-173.

CÍLEK, V. (2007): Chatařství jako fenomén, mentalita a osud. In: Zapletalová, V. (ed.): Chatařství. Architektura lidských snů a možností. Era, Brno, pp. 379-399.

COPPOCK, J.T. (1977): Preface. In: Coppock, J. T. (ed.): Second Homes: Curse or Blessing? Pergamon, Oxford, pp. 6-10.

DAMSGAARD, O. (2007): Second Homes in Denmark. Journal of Nordregio, 3, Second Homes in the Nordic Countries. Nordregio, Stockholm, pp. 19-21.

FIALOVÁ, D., KADLECOVÁ, V., NOŽIČKOVÁ, V., VÁGNER, J. (2009): Changes in second housing in the integrating Europe. In: Wilk, W. (ed): Global changes: their regional and local aspects. FGRS Warsaw University, Warszawa, pp. 171-178.

FIALOVÁ, D., VÁGNER, J. (2009): Sociogeografické aspekty druhého bydlení a jejich regionální diferenciace (na př́kladu Česka). Geografický časopis, 61, No. 2, pp. 89-110.

FLOGNFELDT, T. (2004): Second Homes as a Part of a New Rural Lifestyle. In: Hall, C.M., Müller, D. K. (2004): Tourism, Mobility and Second Homes. Between Elite Landscape and Common Ground. Aspects of Tourism. Channel View Publications, pp. 233-243.

GALLENT, N., SHUCKSMITH, M., TEWDWR-JONES, M., eds. (2003): Housing in the European Countryside: Rural Pressure and Policy in Western Europe. Routledge, London, $269 \mathrm{pp}$.

GARDAVSKÝ, V. (1968): Rekreační zázemí Prahy. Dissertation Thesis. PřF UK, Praha, 91 pp.

GARDAVSKÝ, V. (1977): Second Homes in Czechoslovakia. In: Coppock, J. T. (ed.): Second Homes: Curse or Blessing? Pergamon Press, Oxford, pp. 93-103.

HALL, C.M. (2005): Tourism. Rethinking the Social Science of Mobility. Pearson Educated Ltd., Harlow, 246 pp.

HALL, C.M., MÜLLER, D.K. (2004): Tourism, Mobility and Second Homes. Between Elite Landscape and Common Ground. Aspects of Tourism. Channel View Publications, 302 pp.

HALL, C.M., PAGE, S. (2002): The Geography of Tourism and Recreation. 2nd edition. Routledge. London, $313 \mathrm{pp}$.

HALL, D.R. (1991): Tourism and Economic Development in Eastern Europe and the Soviet Union. Belhaven Press. London, 348 pp.

IGLEBAEK, O. (2007): More Homes but not More People. Journal of Nordregio, 3. Second Homes in the Nordic Countries. Nordregio, Stockholm, p. 3.

JANNSON, B., MÜLLER, D. (2003): Fritidsboende i Kvarken. Kvarkenradet, Umeå.

JOURA, L. (1944): Příspěvek ke studiu sídelních poměrů ve středním Povltaví a přilehlých oblastech. Věstník královské české společnosti nauk, třída pro filozofii, historii a filologii, IV, $31 \mathrm{pp}$.

KADLECOVÁ, V. (2006): Nové trendy v druhém bydlení (se zaměřením na rekreační byty). Bachelor thesis, KSGRR, PřF, UK, Praha, 42 pp.

KALTENBORN, B. P. (1998): The Alternate Home: Motives of Recreation Home Use. Norsk Geografisk Tidsskrift, 52, pp. 121-134.

KOWALCZYK, A. (1994): Geograficzno-spoleczne problemy zjawiska „drugich domow”. Uniwersytet Warszawski. Wydzial Geografii i Studiów Regionalnych, 178 pp.

KUČERA, M. (1992): Hlavní směry dojíždky do objektů individuální rekreace. Zprávy a rozbory ČSÚ, $35 \mathrm{pp}$.

LJUNGDAHL, S.G. (1938): Sommar-Stockholm. Ymer, 58, pp. 218-241.

MARJAVAARA, R. (2008): Second Home Tourism. The Root to Displacement in Sweden? GERUM Kulturgeografi. 1. Department of Social and Economic Geography. Umeå University, Sweden, 226 pp. 
MIEGE, J. (1934): La vie touristique en Savoie. Revue de Geographie Alpine, 22, No. 1, $213 \mathrm{pp}$.

MÜLLER, D.K. (1999): German Second Home Owners in the Swedish Countryside. GERUM Kulturgeografi. 2. Department of Social and Economic Geography. Umeå University, Sweden.

MÜLLER, D.K. (2004): Second Homes in Sweden: Patterns and Issues. In: Hall, C.M., Müller, D.K. (2004): Tourism, Mobility and Second Homes. Between Elite Landscape and Common Ground. Aspects of Tourism. Channel View Publications, pp. 244-260.

MÜLLER, D.K. (2007): Second Homes in the Nordic Countries: Between Common Heritage and Exclusive Commodity. Scandinavian Journal of Hospitality and Tourism, 7, No. 3, pp. 193-201.

NORDIN, U. (1993): Second Homes. In: Aldskogius, H. (ed.): Cultural Life, Recreation and Tourism (National Atlas of Sweden). SNA, Stockholm, pp. 72-79.

PACIONE, M. (1984): Rural Geography. Harper and Law, London, 372 pp.

PÁSKOVÁ, M., ZELENKA, J. (2002): Cestovní ruch - výkladový slovník. MMR ČR, Praha, $448 \mathrm{pp}$.

Population and Housing Census 1991 (SLDB), ČSÚ Praha.

Population and Housing Census 2001 (SLDB), ČSÚ Praha.

POSER, H. (1939): Geographische Studien über den Fremdenverkehr im Riesengebirge. Abhandlungen der Gesselschaft der Wissenschaften zu Göttingen, Math.-Phys., No. 3, p. 20.

SHUCKSMITH, D.M. (1983): Second Homes. Town Planning Review, 54, pp. 179-193.

STEINEKE, J.M. (2007a): The Impact of Recreational Homes. Journal of Nordregio, 3. Second Homes in the Nordic Countries. Nordregio, Stockholm, p. 11.

STEINEKE, J.M. (2007b): Nordic Topography of Second Homes. Journal of Nordregio, 3, Second Homes in the Nordic Countries. Nordregio Stockholm, pp. 12-13.

ŠPRINCOVÁ, S. (1969): Geografie cestovního ruchu v Jeseníkách. SPN, Praha, 235 pp.

TOMBAUGH, L.W. (1970): Factors influencing vacation home locations. Journal of Leisure Studies, 2, No. 1, pp. 54-63.

VÁGNER, J. (2003): První nebo druhé bydlení? Druhé bydlení jako významná složka životního stylu. In: Jančák, V., Chromý, P., Marada, M. (eds.): Geografie na cestách poznání. Sborník přípěvků k šedesátinám Ivana Bičíka. UK v Praze, PřF, KSGRR, pp. 99-106.

VÁGNER, J., FIALOVÁ, D. a kol. (2004): Regionální diferenciace druhého bydlení v Česku. UK v Praze, PřF, KSGRR, Praha, $286 \mathrm{pp}$.

VYSTOUPIL, J. (1981): Geografické problémy krátkodobé rekreace v ČSR. Kandidátská disertační práce. GÚ ČSAV v Brně, manuscript, 146 pp.

VYSTOUPIL, J. (2006): Atlas cestovního ruchu Ceské republiky. MMR ČR, 157 pp.

WILLIAMS, A.M. (2004): Toward a Political Economy of Tourism. In: Lew, A.A., Hall, C.M., Williams, A.M. (eds.): A Companion to Tourism. Blackwell, Oxford pp. 61-73.

WILLIAMS, A., BALÁŽ, V. (2000): Tourism in Transition. Economic Change in Central Europe. I. B. Tauris, London, 188 pp.

WOLFE, R.I. (1977): Summer Cottages in Ontario: Purpose-built for an inessential porpuse. In: Coppock, J.T. (ed.): Second Homes: Curse or Blessing? Pergamon, Oxford, pp. 17-33.

\section{Shrnutí}

\section{DRUHÉ BYDLENÍ VE SVĚTLE HISTORICKOPOLITICKÉHO A SOCIÁLNĚGEOGRAFICKÉHO VÝVOJE: ČESKO A ŠVÉDSKO}

Rostoucí význam volného času, cestovního ruchu a vzrůstající mobilita v současném vyspělém světě mohou být doloženy též dlouhodobým zájmem o vlastnictví a využívání vlastních objektů individuální rekreace (Hall, Müller 2004; Gallent, Shucksmith, Tewdwr-Jones, eds 2003). Trávení volného času v objektech druhého bydlení odráží posun společnosti od industriální k postindustriální, přesun od „turistické společnosti“ ke „společnosti volného času“ (Flognfeldt 2004). Demografické stárnutí populace jakož i rozvoj infrastruktury a technologií vytvořily podmínky pro navýšení podílu domácností, využívajících vlastní rekreační objekt (Müller 2002). 
Zájem o druhé bydlení se odrazil i ve vědeckém výzkumu (Coppock 1977; Hall, Müller 2004). Dle těchto studií se druhé domy převážně vyskytují v oblastech atraktivních i pro komerční formy cestovního ruchu, v oblastech s velkou rozlohou, nízkou hustotou zalidnění a často s pozdním nástupem hlavních urbanizačních procesů. Jsou to právě severské země, kde byly v celoevropském kontextu zaznamenány kořeny těchto forem trávení volného času již velmi časně v 19. století (Müller 2007). Vzhledem k uvedeným charakteristikám může být poněkud překvapivé, že též v Česku kvantitativní i kvalitativní charakteristiky dokládají výrazný význam druhého bydlení též v hodnotovém žebříčku obyvatelstva (Vágner, Fialová a kol. 2004). Nedostatek srovnávacích studií procesů, spjatých s druhým bydlením vyvolal myšlenku pokusit se aplikovat model rozvoje druhého bydlení ve Švédsku na české podmínky.

Tento příspěvek představuje srovnávací studii vývoje, procesů a trendů, spjatých s individuální krátkodobou rekreací ve vlastních objektech (druhým bydlením). Jsou identifikovány hlavní faktory ovlivňující vlastnictví a rozmístění druhého bydlení. Hlavní předpoklad je dán tvrzením, že počátky, ale i některé současné a potenciální trendy ve druhém bydlení jsou analogické v postsocialistické zemi - Česku a v severské zemi s dlouhodobou demokratickou tradicí - Švédsku, navzdory rozdílnému politickému, společenskému a ekonomickému vývoji. Prvotní ideje i proces urbanizace formovaly druhé bydlení podobným směrem, i když s určitými časovými posuny. Studie je výsledkem mezinárodní spolupráce při výzkumu využívání volného času a forem rekreace a cestovního ruchu mezi Univerzitou Karlovou v Praze a Umeå University ve Švédsku.

Vývoj druhého bydlení je charakterizován v několika etapách s odvoláním na hlavní směry výzkumu tohoto fenoménu především od šedesátých let minulého století. Identifikovány jsou hlavní hnací síly a regulační procesy, které ovlivnily nejen absolutní počty, ale též rozmístění objektů druhého bydlení ve zkoumaných regionech, které je podrobně analyzováno. Současný stav a nové formy druhého bydlení jsou spjaty především s procesy internacionalizace a komercializace. Zatímco ve Śvédsku vzrůstá podíl zahraničních vlastníků objektů druhého bydlení, v Česku je v posledním desetiletí fenoménem výstavba rekreačních apartmánů pro bohatou tuzemskou i zahraniční klientelu a rekreačních parků, především pro zahraniční (nizozemské) turisty. Vyrovnávání cen a celkové ekonomické výkonnosti v Evropě přináší nové mezinárodní př́ležitosti - např. zájem Čechů o rybářské chaty u severských jezer, pronájem středomořských rekreačních bytů apod.

Transformace objektů druhého bydlení na bydlení sezónní a trvalé je společným rysem změn ve venkovské krajině v obou zemích. Základní motivy pro vlastnictví druhého bydlení jsou obdobné a korespondují s pojetím Bjerke a kol. (2006). Jedná se o touhu po změně, inverzi každodenního života, neformální životní styl, návrat k př́írodě a venkovskému stylu, význam druhého domu jako investice a v neposlední řadě o možnost vyjádření vlastní identity při budování a údržbě objektu a jeho okolí. Tyto motivy těchto procesů potvrzují deurbanizační tendence - posun od suburbanizace a sezónní migrace směrem k trvalé migraci (Flognfeldt 2004), umožněné rozvojem moderní dopravní infrastruktury a technologií. Díky internetu a mobilním telefonním sítím se stírají i rozdíly mezi bydlištěm, rekreačním objektem a pracovištěm. Chalupaření, na rozdíl od chataření, vykazuje výraznou generační setrvačnost ve využívání objektů a je projevem specifické regionální identity. Roste též zájem o druhé domy v městských aglomeracích. Oživen byl i trh s realitami, kdy objekty druhého bydlení jsou nabízeny k pronájmu, příp. ke komerčnímu využití v rámci cestovního ruchu. Neméně důležitá je možnost uložení kapitálu do nemovitosti i otázka daňová, kdy ve Švédsku neexistuje rozdílné zdanění trvalého bydliště a rekreačního objektu. V českém daňovém systému chybí zohlednění polohy objektu, např. v rámci environmentálně cenné krajiny.

Další výzkum by měl potvrdit význam domácího cestovního ruchu, včetně druhého bydlení, v období ekonomické krize. Hlubší porozumění si zasluhují i socio-kulturní změny ve venkovském prostředí, které jsou přenášeny globalizačními trendy do lokálních měřítek, vztahy mezi starousedlíky a rekreanty. Výzkum těchto jevů a procesů, které budou určovat rozvoj venkovské krajiny i v budoucnu by měl být založen na multidisciplinární spolupráci expertů $\mathrm{z}$ vědeckých i aplikovaných oborů, spjatých $\mathrm{s}$ regionálním rozvojem a vývojem krajiny. 
Obr. 1 - Vývoj druhého bydlení v Česku a Švédsku

Obr. 2 - Rozmístění a počet druhých domů v severských zemích

Obr. 3 -Rozmístění a počet druhých domů v Česku

Authors' affiliations: J. Vágner and D. Fialová are affiliated with Charles University in Prague, Faculty of Science, Dpt. of Social Geography and Regional Development, Albertov 6, 128 43, Praha 2, Czechia; e-mail:vagner@natur.cuni.cz, danafi@natur.cuni.cz.D.K. Müller is affiliated with the University of Umeå, Dpt. of Social and Economic Geography, S-901 87, Sweden; e-mail: dieter.muller@geography.umu.se.

Initial submission, 30 December 2009; final acceptance, 12 January 2011.

Please cite this article as:

VÁGNER, J., MÜLLER, D. K., FIALOVÁ, D. (2011): Second home tourism in light of the historical-political and socio-geographical development of Czechia and Sweden. Geografie, 116, No. 2, pp. 191-210. 